Rev. Biol. Trop. 46(4): 1141-1143, 1998

www.ucr.ac.cr www.ots.ac.cr www.ots.duke.edu

\title{
Nest architecture of group-living wasps Microstigmus (Hymenoptera: Sphecidae): role of the pedicel as a defense against ants
}

\author{
Gretthehun G. Grajales ${ }^{1}$ and Willian T. Wcislo ${ }^{1,2}$ \\ 1 Smithsonian Tropical Research Institute, Apartado 2072 Balboa, República de Panamá. \\ 2 Address correspondence to: W.T. Wcislo, Smithsonian Tropical Research Institute, Unit 0948, APO AA 34002-0948 \\ USA; Fax: 507-232-5978 (Panamá); e-mail: WcisloW@tivoli.si.edu
}

Received 26-II-1998. Corrected 21-VIII-1998. Accepted 10-IX-1998

\begin{abstract}
The nest pedicel of a social sphecid wasp Microstigmus nr. thripoctenus plays an important role in protecting the brood against ant predators, as inferred from data on artificial nests. A pair of artificial nests with or without pedicels was suspended from the undersides of leaves (Carludovica palmata) for $30 \mathrm{~min}$ to assess rates of discovery and removal of food (tuna bait) by ants $(\mathrm{N}=36$ pairs). Three-hundred and forty-three individuals of five ant species removed food at a higher frequency from nests without pedicels (83.3\% of 36 nests) than from nests with pedicels ( $11.1 \%$ of 36 nests).
\end{abstract}

Key words: Brood predation, ants, nest architecture, maternal care, defense.

Ant predation is thought to be a major factor that evolutionarily shaped nest architecture of tropical paper wasps (Hymenoptera: Vespidae) (e.g., Jeanne 1975, Wenzel 1991, Matthews 1991). One nest feature common to many species is a pedicel, a slender support structure for the nest envelope or cells. West-Eberhard (1969) and Jeanne (1972, 1975) hypothesized that its slender form reduces access to the brood by ant predators. Most species in the genus Microstigmus (Hymenoptera: Sphecidae) also construct a pedicel that suspends their nests from the undersides of leaves (Matthews 1968, WestEberhard 1977, Melo and Matthews 1997). Thus, these wasps provide an independant test of West-Eberhard's and Jeanne's hypothesis. To assess the function of the pedicel as a defense, we constructed artificial Microstigmus-like nests with and without pedicels, baited them in the field, and determined the percentage discovered by ants.

\section{MATERIALS AND METHODS}

Observations of natural and artificial nests were made between 22 September and 15 October 1997 on Barro Colorado Island, Republic of Panama (for details on the site, see Leigh et al. 1990). We constructed replicas of nests of Microstigmus nr. thripoctenus by gluing saw-dust to threads (pedicels), and attached them to cells constructed of clay; cells were baited with small pieces of tuna. The dimensions of artificial nests were similar to natural ones (e.g., Matthews 1968, WestEberhard 1977): "pedicels" were $\sim 15 \mathrm{~mm}$, and "nests" were pear-shaped and $\sim 17 \mathrm{~mm}$ long. Additionally, we constructed replicas without pedicels. On each leaf of different individuals of Carludovica palmata R. \& P. 1798 (Cyclanthacea), we attached two artificial nests- one with and one without a pedicel. The thread was inserted into a small hole made 
with a needle, and the artificial nest was suspended from the underside of a leaf. Nonpendant nests were pinned directly to the undersides of leaves. Each of 36 nest pairs were observed for $30 \mathrm{~min}$, and 3 replicates were observed during one day.

Differences in frequencies of attacks by ants on artificial nests with and without pedicels were compared with a $\mathrm{X}^{2}$ test.

Voucher specimens of the model species, Microstigmus nr. thripoctenus, are deposited in the G. B. Fairchild Museum of Invertebrates, University of Panama, and the Snow Entomological Division, Natural History Museum, University of Kansas.

\section{RESULTS}

Nests without pedicels were attacked by 343 individuals of 5 ant species (Ectatomma sp., Pheidole sp., Monomorium sp., Formica sp. and Camponotus sp.), while only 5 individuals of Ectatomma sp. discovered nests suspended from pedicels. Ants removed bait from a significantly greater proportion of artificial nests without pedicels $(83.3 \%$ of 36 trials) than for nests with pedicels $(11.1 \%$ of 36 trials) $\left(x^{2}=37.66\right.$, d.f. $\left.=1, P<0.001\right)$. Nine ants began descending the artificial pedicels, stopped halfway, and returned to the leaf, indicating they were capable of descending the structure.

\section{DISCUSSION}

In our study, ants discovered and removed food more frequently from artificial nests without pedicels than those with pedicels. These findings suggest that this architectural feature can impede ant predation, without a chemically-defended pedicel like that known for some paper wasps (Vespidae) (e.g., Jeanne 1972, 1979; Kojima 1993). Instead, this deterrence may result from a decreased liklihood that ants detect potential food that is farther from the substrate, or from a decreased probability of encountering a nest because the slender pedicel reduces the point of contact between the nest and substrate. Alternatively, the pedicel might be too difficult to descend.

During several hundred hours of observations of nests of $M$. comes in Costa Rica, Matthews and Starr (unpubl. data, cited in Matthews 1991) rarely observed foraging ants crawl onto a nest pedicel, and ant predation does not seem to be a major source of brood mortality in M. comes (Matthews 1991). Matthews and Starr (op. cit.) showed that Solenopsis ants routinely walked down pedicels during experimental manipulations, and thus are capable of reaching a Microstigmus nest. Matthews (1991) suggested that low rates of predation are related to the small biomass in Microstigmus nests, and the small payoff to predators. A slender pedicel further reduces the payoff.

\section{ACKNOWLEDGMENTS}

This study began as GGG's project in a field course sponsored by the Smithsonian Tropical Research Institute (STRI), and was continued with support from STRI general research funds to WTW. Gabriel Melo kindly helped with identifying the Microstigmus, and Mary Jane West-Eberhard provided helpful and incisive comments on an earlier draft.

\section{RESUMEN}

La suspensión pedicelar en la arquitectura del nido de la avispa social Microstigmus nr. thripoctenus juega un importante papel en la protección de las crías contra los depredadores, especialmente hormigas, basado de estudios con nidos artificiales. Debajo de las hojas de Carludovica palmata un nido artificial con pedicelo $y$ otro sin pedicelo fueron suspendidos por $30 \mathrm{~min}$ para determinar la frecuencia de descubrimiento $y$ eliminación de un cebo (atún) $(\mathrm{N}=36$ pares). El porcentaje de depredación fue menor $(11.1 \%)$ en los nidos con pedicelo que en nidos sin pedicelo (83.3\%). Se observaron 343 individuos de cinco especies de hormigas atacando los nidos artificiales. 


\section{REFERENCES}

Jeanne, R.L. 1972. Social biology of the neotropical wasp Mischocyttarus drewseni. Bull. Mus. Comp. Zool., Harvard Univ. 144: 63-150.

Jeanne, R.L. 1975. The adaptiveness of social wasp nest architecture. Q. Rev. Biol. 50: 267-287.

Jeanne, R.L. 1979. A latitudinal gradient in rates of ant predation. Ecology 60: 1211-1225.

Kojima, J. 1993. A latitudinal gradient in intensity of applying ant-repellent substance to the nest petiole in paper wasps (Hymenoptera: Vespidae). Insectes Soc. 40: 403-421.

Leigh, E.G., Jr, Rand, A.S. \& D.W. Windsor (eds.). 1990. Ecología de un Bosque Tropical (Traducción de 1982). Smithsonian, Washington, D.C.

Matthews, R.W. 1968. Nesting biology of the social wasp Microstigmus comes (Hymenoptera: Sphecidae, Pemphredoninae). Psyche 75: 23-45.
Matthews, R.W. 1991. Evolution of social behavior in sphecid wasps, pp. 570-602. In: K. G. Ross and R.W. Matthews (eds.), The Social Biology of Wasps. Cornell University, Ithaca, New York.

Melo, G.A.R. \& R. W. Matthews. 1997. Six new species of Microstigmus wasps (Hymenoptera: Sphecidae), with notes on their biology. J. Nat. Hist. 31: 421437.

Wenzel, J.W. 1991. Evolution of nest architecture, pp. 480519. In: K. G. Ross and R.W. Matthews (eds.), The Social Biology of Wasps. Cornell University, Ithaca, New York.

West-Eberhard, M.J. 1969. The social biology of polistine wasps. Misc. Publ. Mus. Zool. Univ. Michigan 140: $1-101$.

West-Eberhard, M.J. 1977. Morphology and behavior in the taxonomy of Microstigmus wasps, pp. 123-125. Proc. VIII Internatl. Congr. Internatl. Soc. Study Soc. Insects (Wageningen). 